\title{
Processus iudiciarius secundum stilum Pragensem (výsledky projektu)
}

\section{O M IN IK BUDSKÝ}

Tato stat' chce informovat o výsledcích projektu Processus iudiciarius secundum stilum Pragensem a zároveň nastínit další výzkumné perspektivy v oboru dějin kanonického práva ve středověku.

Hlavním výsledkem projektu podpořeným dvěma navazujícími granty Grantové agentury Univerzity Karlovy je edice středověkého kanonickoprávního traktátu Processus iudiciarius secundum stilum Pragensem sepsaného v 80. letech 14. stol. oficiálem arcibiskupa pražského a kanovníkem Metropolitní kapituly Mikulášem Puchníkem († 1402).

Nezbytnou součástí projektu je publikační činnost, která vedle několika konferenčních prríspěvků zahrnuje i samostatně publikované studie v domácích (Mediaevalia Historica Bohemica, Acta iuridica Olomucensia, Studie o rukopisech) i zahraničních recenzovaných časopisech (Zeitschrift der Savigny-Stiftung für Rechtgeschichte-Kanonistische Abteilung). Jde především o biografii autora traktátu Mikuláše Puchníka, kanonickoprávní rozbor díla a rozbor všech dochovaných rukopisů.

Zmíněná biografie přitom nepostrádá řadu zajímavých momentů. Mikuláš Puchník patřil mezi vrstevníky a kolegy Jana z Pomuku a spolu s ním zažil i běsnění krále Václava IV. v březnu roku 1393, ze kterého ovšem vyvázl relativně bez úhony.

Stejně tak i obsahový rozbor Puchníkova díla přinesl řadu důležitých poznatků. Zkoumané dílo bylo podrobeno obsahové i stylistické komparaci s několika časově i tematicky blízkými traktáty a posléze se podařilo prokázat, že Processus iudiciarius je projevem, ve středověku poměrně vzácné, „autorské originality“ spočívající jak ve struktuře tak stylu.

Edice byla prozatím zpracována s použitím čtyř nejstarších rukopisů sahajících svým vznikem ještě do 14. stol. Dalších devět rukopisných dochování díla na své zapracování do podoby úplné kritické edice a následné monografické vydání ještě čeká.

Řešitel projektu se během svého výzkumu zúčastnil mezinárodního kongresu ICMAC (Iuris Canonici Medii Aevi Consociatio) v Torontu (2012). Kongres pořádaný ve čtyřletých intervalech je hlavní událostí daného oboru za účasti badatelů z celého světa. Jedná se o významnou př́ležitost k setkávání i vzájemným konzultacím. Tematika příspěvků na těchto kongresech je velmi široká a kromě vlastního normativního práva si všímá i práva procesního, synodálního, průniků mezi kanonickým právem a teologií a v neposlední řadě také práva obyčejového a nových publikací-edic. Mezi nejzajímavější 
příspěvky (z hlediska mého badatelského zaměření) patřily nepochybně přednášky Susan L'Engle Glossing the Margins: Strategies for Learning the Law a profesora práv na harvardské univerzitě Charlese Donahue, jehož nejnovější kompendium z oblasti manželského práva vzbuzuje zaslouženou pozornost odborné veřejnosti. ${ }^{1}$

Samotná badatelská činnost nebyla pro předkladatele disertace a zpracovatele projektu nikterak snadnou z toho důvodu, že na domácí půdě byla dějinám kanonického práva (nejen) ve středověku věnována pozornost jen nahodile a mezerovitě. $\mathrm{V}$ otázkách juristických se tak bylo nutné spolehnout do značné míry na zahraniční literaturu a semináře pro doktorandy pořádané organizací CLASMA na univerzitě v Cambridge.

Závěrem nezbývá než popřát české kanonistice badatelsky produktivnější období a více nových výzkumných pracovníků i projektů a vyjádřit velký dík Katolické teologické fakultě UK za podporu po celou dobu doktorského studia.

1 DONAHUE, Charles. Law, Marriage, and Society in the Later Middle Ages: Arguments about Marriage in Five Courts. Cambridge: Cambridge UP, 2008. 